\title{
ANALISIS KONSEPTUAL TEORETIK PENDIDIKAN KEWIRAUSAHAAN SEBAGAI SOLUSI DAMPAK ERA INDUSTRI 4.0 DI INDONESIA
}

\author{
Sumarno $^{1}$ dan Gimin ${ }^{1}$ \\ ${ }^{1}$ Pendidikan Ekonomi, Fakultas Keguruan dan Ilmu Pendidikan, Universitas Riau \\ e-mail:sumarno.s@lecturer.unri.ac.id
}

\begin{abstract}
This article aims to find out entrepreneurial education as a solution to the impact of the industrial era 4.0 (E.I.4.0). The data were collected by documentation techniques and observation, and then analyzed using descriptive exploratory techniques. The results indicate that E.I.4.0 had a negative impact is the loss of various jobs, but on the other hand had a positive impact, that are the emergence of business and employment opportunities. In E.I.4.0, human resources are required to have the ability to create, innovate, think critically, and collaborate and self-confidence. Entrepreneurship education provides knowledge and skills and develops attitudes that can be a solution to the impact of E.I 4.0. Entrepreneurial knowledge, skills and attitudes will shape human beings in accordance with E.I.4.0, which were the ability to create, innovate, think critically, collaborate, and be confident. This ability will be able to reach opportunities that arise in order to replace lost jobs. At the level of pre-school education, basic education and general secondary education (SMA/MA), entrepreneurship education should be emphasized more on developing entrepreneurial attitudes and knowledge. At the level of vocational secondary education (SMK/MAK) and higher education, entrepreneurship education should be emphasized more on the development of entrepreneurial skills. Effective implementation of entrepreneurship education for E.I.4.0 requires synergy and integration between subjects or subjects, teachers / lecturers, education levels, and among various stakeholders in a sustainable.
\end{abstract}

Keywords: Industrial era 4.0, entrepreneurship, entrepreneurship education.

\section{PENDAHULUAN}

Walaupun lambat dibanding negara-negara maju, Indonesia sudah masuk dalam era industri 4.0. Menurut Faisal, Direktur Penelitian Center of Reform on Economics (CORE), menyatakan bahwa gejala revolusi industri 4.0 mulai tampak pada industri padat modal dan tren investasi tahun 2017 yang cenderung masuk ke industri minim tenaga kerja (Angriani, 2018). Industry 4.0 menggunakan teknologi utama Cyber-Physical System (CPS), yaitu kombinasi sistem fisik dan cybernetic (Klingenberg, 2017). CPS memfasilitasi perbaikan mendasar untuk proses industri yang terlibat dalam manufaktur, teknik, penggunaan material, rantai pasokan, dan manajemen siklus hidup (Haeffner \& Panuwatwanich, 2018). Sistem tersebut akan membawa perusahaan menjadi smart, akibatnya peran manusia akan tergeser (Kagermann, Wahlster, \& Helbig, 2013) pekerjaan manusia banyak digantikan oleh mesin dan robot sehingga orang yang terlibat dalam produksi semakin sedikit (Haeffner \& Panuwatwanich, 2018). Wolter et.al juga menyatakan hal yang sama bahwa tantangan yang dihadapi dalam era industri 4.0 antara lain berkurangnya banyak pekerjaan karena proses teknologi informasi dan otomatisasi (Sung, 2018).

Berkenaan dengan kehidupan di era industri 4.0, Herlambang, (2018) mengungkapkan bahwa manusia Indonesia harus memiliki kompetensi utuh sebagai bekal kehidupan dewasa ini yaitu sikap keterbukaan dan keterampilan berpikir kritis, berpikir kreatif, dapat berkomunikasi dan berkolaborasi. Agar manusia memiliki bekal kompetensi tersebut diperlukan adanya pendidikan. Terkait dengan pendidikan, Moravec menyatakan bahwa industri 4.0 menuntut pendidikan melompat dari kerangka pendidikan 2.0 atau 3.0 saat ini ke pendidikan 4.0, yaitu pendidikan yang membangun praktik inovasi individu maupun tim atau memberdayakan siswa untuk menghasilkan inovasi, sebagai tindak lanjut produksi pengetahuan pada pendidikan 3.0 (Harkins, 2008; Diwan, 2017). Sejalan dengan itu, Cepi Riyana mengungkapkan bahwa tantangan pendidikan di era revolusi industri 4.0 berupa perubahan dalam mengembangkan inovasi kreatif di berbagai bidang (Kautsar \& Ibrahim, 2018). 
Menurut Tilaar (2012), apabila Indonesia mau mengadakan quantum leap untuk dapat sejajar dengan bangsa yang telah maju, maka pendidikan entrepreneur harus digalakkan, karena sikap entrepreneur (entrepreneurship) merupakan tingkah laku (behavior) yang diadasarkan pada kemampuan berpikir kreatif dan invatif. Pertanyaannya yang timbul dan perlu dijawab berkenaan dengan pendidikan untuk era industri 4.0 adalah "Apakah pendidikan kewirausahaan dapat menjadi solusi bagi kehidupan manusia di era industri 4.0 Indonesia? Bagaimana mengimplementasikan pendidikan tersebut secara lebih efektif pada jenjang pendidikan yang ada?". Untuk menjawab pertanyaan tersebut, perlu dikaji tentang konsep teoretik pendidikan kewirausahaan sebagai solusi dampak era industri 4.0 Indonesia.

\section{METODE}

Kajian untuk menjawab pertanyaan di atas ini dilakukan dengan menggunakan pendekatan deskriptif eksploratif. Data dikumpulkan dengan teknik dokumentasi dan observasi. Dokumentasi digunakan untuk mengumpulkan data tentang konsep dan teori pendidikan kewirausahaan serta dampak dan tuntutan era industri 4.0. Di samping itu juga digunakan untuk mengumpulkan hasilhasil penelitian yang terkait keduanya. Analisis data menggunakan teknik deskriptif eksploratif untuk mendapatkan gambaran tentang fungsi pendidikan kewirausahaan sebagai solusi atas dampak yang muncul dari era industri 4.0, baik dampak negatif maupun dampak positif, serta solusi atas tuntutan terhadap kompetensi sumber daya manusia era industri 4.0.

\section{PEMBAHASAN}

\section{Pendidikan Kewirausahaan}

Pendidikan kewirausahaan diartikan sebagai isi, metode, dan aktivitas yang mendukung pengembangan motivasi, kompetensi, dan pengalaman yang membuatnya memungkinkan untuk menerapkan, mengelola, dan berpartisipasi dalam proses pemberian nilai tambah (Rasmussen, Moberg, \& Revsbech, 2015). Pendidikan kewirausahaan yang mencakup isi, metode, dan aktivitas ditujukan untuk memberikan/mengembangkan pengetahuan, pola pikir, sikap, motivasi, keterampilan, dan pengalaman kewirausahaan (Sumarno, Gimin, Haryana, \& Saryono, 2018), sedangkan tujuan pendidikan kewirausahaan untuk universitas adalah bekerja dengan orang lain; pengembangan berbagai bentuk bisnis; kompetensi pribadi: kepekaan sosial, kepercayaan diri, empati, berpikir kritis, pengambilan keputusan, dan orientasi tindakan (Čapienè \& Ragauskaite, 2017). Konten aktif dalam pendidikan kewirausahaan bagi lulusan untuk mendapatkan pengetahuan, keterampilan dan kompetensi serta niat positif menuju memulai bisnis melalui pengalaman (Williamson, Beadle, \& Charalambous, 2013). Dalam pendidikan kewirausahaan, metode yang direkomendasikan adalah metode belajar berbasis pengalaman atau tindakan seperti simulasi, kunjungan/ekslporasi perusahaan, menulis rencana bisnis (Weber \& Funke, 2012). Di samping itu juga dapat melakukan sesuatu yang praktis dan kesempatan untuk mempertanyakan, menyelidiki, berbicara, dan berdiskusi dengan para wirausahawan, memberikan pengetahuan dan keterampilan serta menstimulasi sikap (Arasti, Mansoreh, \& Imanipour, 2012). Untuk melatih dan atau mengembangkan kreativitas, dapat dilakukan melalui 4P yaitu: 1) Pembentukan pribadi kreatif, 2) Motivasi Pendorong kreativitas, 3) Proses kreativitas, dan 4) Produk kreatif (Kodrat \& Christina, 2015).

Bagi Indonesia, kewirausahaan itu penting karena Indonesia membutuhkan kebijakan baru yang mendorong semangat entrepreneurship agar tercapai pertumbuhan ekonomi yang stabil (Handrimurtjahjo, 2013) karena jumlah wirausahawan di Indonesia baru sekitar 1,6 persen (Sumarno \& Suarman, 2017) atau kurang dari 2\% (Jati \& Priyambodo, 2015). Selain itu, pendidikan merupakan hal yang penting untuk menstimulasi kewirausahaan; dan hubungan yang positif dan kuat antara pendidikan dan kinerja kewirausahaan juga telah terbukti (Raposo \& Paço, 
2011).

Pendidikan kewirausahaan sebaiknya dilaksanakan secara terpisah dan secara terintegrasi. Secara terpisah yaitu dengan cara mengadakan pelajaran atau perkuliahan kewirausahaan yang menjadi mata pelajaran atau mata kuliah tersendiri dan tercantum dalam kurikulum. Secara terintegrasi dilaksanakan melalui mata pelajaran atau mata kuliah non-kewirausahaan dengan cara mengkaitkan unsur-unsur kewirausahaan dalam pembelajaran atau perkuliahan non-kewirausahaan (Sumarno et al., 2018). Di samping melalui intra kurikuler (pembelajaran atau perkuliahan), pendidikan kewirausahaan sebaiknya juga dilaksanakan melalui kegiatan-kegiatan co-kurikuler maupun ekstra kurikuler (dalam perguruan tinggi dikenal dengan unit kegiatan mahasiswa). Cokurikuler bersifat penunjang mata pelajaran atau mata kuliah seperti praktek lapangan, pendirian koperasi siswa, atau unit produksi sekolah; sedangkan ekstra kurikuler bersifat tidak menunjang mata pelajaran atau mata kuliah secara langsung seperti klub siswa/mahasiswa kreatif.

Pendidikan kewirausahaan penting untuk menciptakan SDM yang memiliki kecakapan kreatif dan inovatif serta kecakapan sosial lainnya. Menurut Bourgeois (2012), pendidikan kewirausahaan sangat penting tidak hanya untuk membentuk pola pikir kaum muda, tetapi juga untuk memberikan keterampilan dan pengetahuan yang penting untuk mengembangkan budaya kewirausahaan. Selain itu, pentingnya pendidikan kewirausahaan bagi penyiapan SDM di era industri 4.0 juga karena alasan adanya peningkatan digitalisasi manufaktur yang didorong oleh munculnya analisis, kemampuan, dan kecerdasan bisnis (Lee, Lapira, Bagheri, \& Kao, 2013). Untuk dapat memenuhi kebutuhan itu, maka pendidikan kewirausahaan harus dapat dilaksanakan secara kolaboratif antar berbagai pihak baik dalam bentuk pelatihan maupun pendidikan. Pendidikan kewirausahaan tidak hanya penting bagi perguruan tinggi tetapi dipersiapkan sejak pendidikan dasar bahkan sejak pendidikan usia dini (Tilaar, 2012).

\section{Dampak Negatif Revolusi Industri 4.0 Bagi Tenaga Kerja}

Berkembangnya teknologi digital pada era industri 4.0 ditandai adanya revolusi internet yang dikenal dengan internet of thing dan juga munculnya robot-robot yang akan mendisrupsi manusia menggantikan pekerjaan mereka sehingga menimbulkan pengangguran (Safuan, 2018) atau distraktif terhadap pekerja (Angriani, 2018). Pekerjaan-pekerjaan yang sebelumnya dilakukan oleh manusia, digantikan oleh sistem digital internet dan robot. Akibatnya pada era industri 4.0 akan banyak pekerjaan hilang (Harususilo, 2018; Safuan, 2018) yaitu 35\% job (jenis pekerjaan) yang dipelajari di perguruan tinggi saat ini akan hilang dalam 5 tahun mendatang dan $75 \%$ job akan hilang pada 10 tahun mendatang (Linangkung, 2017). Organisasi Buruh Internasional (ILO) juga memproyeksikan bahwa Indonesia akan memindahkan 56 persen pekerjaan ke otomatisasi pada beberapa dasawarsa mendatang (Tanaya, 2018). Akibat dari itu semua adalah meningkatnya pengangguran sebagai hasil akumulasi dari tenaga kerja yang kehilangan pekerjaan dan pertumbuhan angkatan kerja baru yang tidak mendapatkan pekerjaan.

\section{Dampak positif revolusi industri 4.0 bagi tenaga kerja}

Selain dampak negatif yang muncul, revolusi industri 4.0 sebenarnya memunculkan dampak positif. Revolusi industri 4.0 memiliki potensi besar yang akan menghasilkan cara-cara baru untuk menciptakan nilai dan model bisnis baru, yang akan menyediakan kesempatan untuk mengembangkan dan menyediakan layanan hilir (Kagermann et al., 2013). Industri 4.0 membawa perubahan yang luas, oleh karena itu, pengembangan Industri 4.0 tidak hanya akan membuka peluang bagi industri manufaktur, tetapi juga membuka peluang baru lainnya untuk membuat perkembangan ini terjadi; banyak pekerjaan baru yang diciptakan (Haeffner \& Panuwatwanich, 2018; Safuan, 2018). Revolusi industri 4.0 menginisiasi lahirnya model bisnis baru dengan strategi lebih inovatif dan disruptif dengan cakupan yang luas mulai dari dunia bisnis, perbankan, transportasi, sosial masyarakat, hingga pendidikan (Suwardana, 2017).

Adanya efektivitas dan efisiensi industri di era industri 4.0 secara tersembunyi mengindikasikan adanya potensi peluang usaha yang lebih menarik yang pada gilirannya akan 
meningkatkan peluang kerja. Industry 4.0 mendorong peningkatan efisiensi dan produktivitas gaya hidup kita saat ini, yang salah satunya mengarah ke penciptaan produk dan pasar baru (Diwan, 2017). Menurut Irianto (2017), industri 4.0 memiliki peluang: innovation ecosystems, competitive industrial base, investment on technologies, dan integrate SME \& enterpreneurship.

\section{Tuntutan Kompetensi Era Industri 4.0}

Pada era industri 4.0, tugas pekerjaan yang bersifat manual berulang sederhana akan digantikan oleh robot dan mesin, tenaga kerja (manusia) akan mengambil alih tugas yang terkait dengan manajemen, oleh karenanya memerlukan keterampilan pribadi yang lebih kuat seperti komunikasi, koordinasi, dan keterampilan lunak lainnya untuk mengambil alih tanggung jawab dan pengambilan keputusan (Haeffner \& Panuwatwanich, 2018). Menurut Andoko (Harususilo, 2018), ada beberapa kompetensi yang dibutuhkan untuk mempersiapkan era industri 4.0 diantaranya adalah kemampuan memecahkan masalah (problem solving), beradaptasi (adaptability), kolaborasi (collaboration), kepemimpinan (leadership), dan kreatifitas serta inovasi (creativity and innovation). Menurut Brodjonegoro (2018), kecakapan era 4.0 adalah kemampuannya dalam menangani persoalan yang kompleks melalui kecakapan non-rutin dan kecakapan sosial. Menurut Muhadjir Effendy, Menteri Pendidikan dan Kebudayaan Indonesia, ada lima kemampuan yang harus dimiliki generasi muda dalam rangka menghadapi revolusi industri keempat ialah kemampuan berpikir kritis, kreatif dan inovatif, kemampuan berkomunikasi, kemampuan bekerja sama, dan percaya diri, sebagai modal yang sangat dibutuhkan untuk bisa masuk abad 21 dan menguasai serta bergaul dalam revolusi industri 4.0 (Ariyanti, 2018). Untuk memenuhi tuntutan kompetensi era industri 4.0 maka diperlukan literasi baru dengan kemampuan komunikasi, kolaborasi, berpikir kritis, kreatif dan inovatif (Suwardana, 2017).

\section{Pendidikan Kewirausahaan Sebagai Solusi Dampak dan Tuntutan Era Industri 4.0}

Sebagaimana diungkapkan dimuka, pendidikan kewirausahaan merupakan isi, metode, dan aktivitas yang mendukung pengembangan kompetensi kepekaan sosial, kepercayaan diri, empati, berpikir kritis, pengambilan keputusan, dan orientasi tindakan untuk menerapkan, mengelola, dan berpartisipasi dalam proses pemberian nilai tambah. Konten aktif dalam pendidikan kewirausahaan adalah pengetahuan, keterampilan dan kompetensi serta niat positif. Menurut Mulyani dkk., nilainilai pokok kewirausahaan dapat dirinci menjadi 17, yaitu: 1) mandiri, 2) kreatif, 3) berani mengambil resiko, 4) berorientasi pada tindakan, 5) kepemimpinan, 6) kerja keras, 7) jujur, 8) disiplin, 9) inovatif, 10) tanggungjawab, 11) kerjasama, 12) pantang menyerah, 13) komitmen, 14) realistis, 15) rasa ingin tahu, 16) komunikatif, dan 17) motivasi kuat untuk sukses (Mulyani et al., 2010).

Untuk dapat memiliki pekerjaan atau meraih peluang (kerja dan usaha) di era industri 4.0, sumber daya manusia dituntut memiliki kompetensi atau kemampuan yang berkenaan dengan berpikir kritis, kreatif, inovatif, berkomunikasi, bekerja sama, dan percaya diri, dan lainnya. Kemampuan tersebut sangat terkait dengan kompetensi dan nilai-nilai kewirausahaan. Tuntutan kemampuan era industri 4.0 tersebut ternyata juga terkait erat dengan atau jiwa dan sikap wirausaha atau wiraswastawan; dan juga sesuai dengan inti dari kewirausahaan yaitu kreativitas dan inovasi (Alma, 2010; Jati \& Priyambodo, 2015; Sumarno \& Suarman, 2017). Proses kreatifitas hanya dilakukan oleh orang-orang yang memiliki jiwa dan sikap kewirausahaan (Suryana, 2013).

Bila disimak, dapat dengan jelas diketahui bahwa kemampuan yang dituntut dari era industri 4.0 (antara lain berupa kemampuan berpikir kritis, kreatif dan inovatif, berkomunikasi, bekerja sama, percaya diri, berkoordinasi, tanggung jawab, mengambil keputusan, memecahkan masalah, beradaptasi, dan kepemimpinan) merupakan nilai-nilai pokok atau jiwa dan sikap kewirausahaan yang dihasilkan dari pendidikan kewirausahaan. Artinya bahwa pendidikan kewirausahaan dapat menjadi solusi atas tuntutan era industri 4.0, karena melalui pendidikan kewirausahaan, kemampuan atau kompetensi sumber daya manusia yang dituntut era industri 4.0 dapat dipenuhi. Terpenuhinya tuntutan kemampuan sumber daya manusia pada era industri 4.0, 
akan mampu meraih dampak positifnya yang berupa peluang usaha baru seperti: cara-cara baru untuk menciptakan nilai dan model bisnis baru, pengembangan dan penyediaan layanan hilir, penciptaan produk dan pasar baru, innovation ecosystems, competitive industrial base, investment on technologies, dan integrate SME \& enterpreneurship. Bila peluang usaha yang ada dapat diraih, maka tercipta peluang kerja yang baru. Peluang kerja yang baru dapat diraih karena kemampuan sumber daya manusia yang ada sudah sesuai tuntutannya. Diraihnya peluang kerja dan peluang usaha era industri 4.0, akan mengatasi dampak negatifnya yang berupa pengangguran akibat pergeseran pekerjaan. Hal yang demikian menunjukkan bahwa pendidikan kewirausahaan dapat menjadi solusi atas dampak era industri 4.0.

\section{Implementasi Pendidikan Kewirausahaan}

Pendidikan kewirausahaan ditujukan untuk membentuk dan mengembangkan sikap, pengetahuan, keterampilan, dan pengalaman kewirausahaan. Pembentukan sikap kewirausahaan seharusnya dimulai dari jenjang pendidikan pra sekolah, seperti Pendidikan Anak Usia Dini (PAUD). Education, Audiovisual and Culture Executive Agency juga menyatakan bahwa pendidikan adalah kunci untuk membentuk sikap, keterampilan, dan budaya anak muda, maka pendidikan kewirausahaan harus ditangani sejak usia dini (Bourgeois, 2012). Membangun nilainilai atau sikap kewirausahaan pada anak usia dini lebih kepada bagian membangun sifat dan karakter yang mandiri dan bertanggungjawab melalui pendidikan wirausaha secara teoritis maupun praktis, serta contoh nyata (Santika, 2017). Metode pendidikan kewirausahaan pada jenjang pra sekolah cocok dilaksanakan melalui pendekatan bermain dan atau kegiatan-kegiatan yang mengandung prinsip bermain.

Pendidikan kewirausahaan pada jenjang pendidikan dasar Sekolah Dasar (SD) antara lain berkenaan dengan berbagai keterampilan akademik dan keterampilan sosial (soft skill) yang berupa berpikir kritis, berpikir kreatif, berkomunikasi jelas, asertif, dan solutif (Zuchdi, Prasetya, \& Masruri, 2013). Selain itu, nilai-nilai inovatif, mandiri, nilai tambah, berani mengambil risiko, dan mampu melihat peluang juga dapat dituangkan dalam kurikulum kewirausahaan di sekolah dasar (Suryaman \& Karyono, 2017). Hasil penelitian di Maroko menunjukkan bahwa anak usia 11-12 tahun merupakan periode yang cukup untuk mengembangkan self-efficacy, keterampilan nonkognitif yang dibutuhkan untuk menjadi wirausaha (Hassi, 2016). Pendidikan kewirausahaan yang berkenaan dengan karakter dapat dilaksanakan secara terintegrasi dalam semua mata pelajaran, kegiatan ekstrakurikuler, dan kegiatan pembiasaan. Di samping itu, juga dapat dilakukan melalui kegiatan Market Day secara rutin sehingga siswa mengenal kegiatan berdagang kemudian terbiasa, dan dari kebiasaan tersebut tumbuh dalam diri siswa karakter wirausahawan yaitu: rasa percaya diri, berani mengambil resiko, bertanggungjawab, komunikatif serta terbiasa untuk memiliki ide barang jualan, dan mengatur keuangan, serta memimpin (Sulistyowati \& Salwa, 2016). Pendidikan kewirausahaan dengan Program "My first company: Entrepreneurship by Playing" di SD ternyata dapat mengembangkan kemampuan kewirausahaan siswanya baik yang berupa pengetahuan, skill, nilai-nilai, maupun pengalaman kewirausahaannya (Carcamo-Solís, Arroyo-Lopez, AlvarezCastanon, \& García-Lopez, 2017). Pendidikan kewirausahaan untuk jenjang pendidikan SD juga mengembangkan keterampilan kewirausahaan secara terintegrasi pada Mata Pelajaran (Mapel) Seni Budaya dan Prakarya. Mapel tersebut diarahkan untuk memunculkan kreativitas peserta didik, yang ditekankan untuk mengembangkan ide-ide melalui pendekatan naturalistik, dan dibelajarkan dengan pendekatan tematik (Kemdikbud RI, 2016).

Tidak beda dengan SD, pendidikan kewirausahaan di Sekolah Menengah Pertama (SMP) juga meliputi penanaman nilai-nilai percaya diri, kreatif, berpikiran ke depan, berorientasi kepada hasil, kerja keras, ber-tanggung jawab, inovatif dan jujur (Saputra, 2011). Selain itu juga karakter kepemimpinan, tanggung jawab, disiplin, kreatif, inovatif, berani mengambil resiko, kerja keras, motivasi kuat, pantang menyerah, kerja sama, dan komunikatif (Syaifuddin \& Kalim, 2016). Untuk penanaman dan pengembangan karakter kewirausahaan di SMP dapat dilakukan melalui kegiatan rutin, kegiatan spontan, pemodelan, pengajaran, dan penguatan lingkungan sekolah (Safitri, 2015). 
Pengembangan minat kewirausahaan siswa SMP dapat diintegrasikan pada pelajaran melukis dengan pendekatan scientific sell, yaitu pendekatan ilmiah ditambah kegiatan menjual hasil ciptaan melukisnya (Fitroni, 2017). Pengembangan aspek kewirausahaan dari kajiannya Fitroni sebenarnya tidak hanya nilai-nilai karakter atau sikap dan jiwa kewirausahaan saja, tetapi sudah dapat dikembangkan aspek pengetahuan dan keterampilannya. Pengetahuan kewirausahaan yang dapat diungkap atau ditanamkan kepada siswa seperti konsep menjual, kuntungan, dan promosi; sedangkan keterampilan kewirausahaannya yaitu keterampilan memproduksi atau membuat lukisan, mempromosikan, dan menjualnya kepada konsumen serta menghitung biaya dan keuntungannya. Menurut Mulyani et al., (2010), nilai-nilai kewirausahaan yang dapat diintegrasikan di SMP sederajat meliputi mandiri, kreatif, berani mengambil risiko, berorientasi pada tindakan, kepemimpinan, kerja keras, konsep, dan skill/keterampilan. Dimulainya penanaman aspek pengetahuan dan keterampilan kewirausahaan pada jenjang pendidikan SMP sesuai dengan tujuan SMP yang antara lain membangun landasan bagi berkembangnya potensi peserta didik agar menjadi manusia yang berilmu, cakap, kritis, kreatif, dan inovatif, mandiri, dan percaya diri. Pengembangan pengetahuan dan keterampilan kewirausahaan pada jenjang pendidikan SMP diitegrasikan melalui Mapel Prakarya. Mapel ini diarahkan pada pengembangan keterampilan dilakukan pada tingkat manipulasi (modifikasi) yang diarahkan untuk menghasilkan produk. Pada mapel ini, pembentukan nilai keterampilan kewirausahaan dilakukan melalui penyelarasan antara kemampuan dan minat dengan motif berwirausaha yang bertujuan melatih koordinasi otak dengan keterampilan teknis (Kemdikbud RI, 2016).

Pendidikan kewirausahaan untuk jenjang pendidikan menengah sudah mulai mengarah pada pengembangan pengetahuan dan keterampilan kewirausahaan yang lebih luas dan dalam. Pada Sekolah Mengah Atas (SMA) atau Madrasah Aliyah (MA), lebih ditekankan pada aspek pengetahuannya. Namun demikian, aspek sikap atau karakter kewirausahaan tetap perlu dikembangkan. Pengembangan pengetahuan dan keterampilan kewirausahaan pada jenis pendidikan SMA juga dilakukan pada sebagian besar negara-negara di Eropa (Bourgeois, 2012). Di Indonesia, pengembangan pengetahuan dan keterampilan kewirausahaan dilaksanakan secara terintegrasi, seperti Mata Pelajaran (Mapel) Ekonomi untuk aspek pengetahuan dan keterampilan kewirausahaan, dan Mapel lainnya untuk aspek sikap kewirausahaan; dan juga secara terpisah melalui Mapel tersendiri yaitu Prakarya dan Kewirausahaan. Mapel tersebut mengembangkan pengetahuan dan keterampilan kecakapan hidup berbasis seni, teknologi dan ekonomi, melatih keterampilan mencipta karya, melatih memanfaatkan media dan bahan berkarya seni dan teknologi, serta menumbuh kembangkan jiwa wirausaha melalui melatih dan mengelola penciptaan karya (produksi), mengemas, dan usaha menjual (Werdhaningsih, Haryudanti, Jamrianti, \& Wirmas, 2017). Hasil penelitian Hermansyah, Natuna, \& Sumarno (2017) mengungkapkan bahwa pelaksanaan pembelajaran kewirausahaan dapat membentuk karakter kewirausahaan di kalangan peserta didik. Latihan-latihan keterampilan dalam pembelajaran prakarya dan kewirausahaan memberikan pengalaman praktik kewirausahaan peserta didik. Menurut hasil penelitian (Faidah, Harti, \& Subroto, 2018), pengalaman ekonomi berpengaruh signifikan dan positif terhadap perilaku ekonomi siswa. Pengalaman ekonomi dan perilaku ekonomi berkenaan dengan kegiatan atau aktivitas kewirausahaan yang berupa memproduksi, mengemas, dan menjual produk secara menguntungkan. Pengalaman dan perilaku ekonomi dapat diimplementasikan melalui Koperasi Siswa.

Untuk Sekolah Menengah Kejuruan (SMK) atau Madrasah Aliyah Kejuruan (MAK), pendidikan kewirausahaan juga dilaksanakan secara terintegrasi dan terpisah. Pelaksanaan secara terintegrasi yaitu melalui Mapel lain dalam Kelompok Mapel Umum untuk pengembangan sikap kewirausahaan dan dalam Kelompok Mapel Muatan Peminatan Kejuruan (Kelompok Dasar Bidang Keahlian, Dasar Program Keahlian, dan Kompetensi Keahlian) untuk pembentukan dan pengembangan keterampilan. Di samping itu, ada Mapel Produk Kreatif dan Kewirausahaan sebagai Mapel tersendiri yang merupakan pelaksanaan pendidikan kewirausahaan secara terpisah. Mapel ini merupakan perubahan atas Mapel Prakarya dan Kewirausahaan yang ada pada kurikulum 
2013 sebelum revisi 2017. Mapel Produk Kreatif dan Kewirausahaan mengintegrasikan bidang/program/kompetensi keahlian kedalam kewirausahaan, yaitu mempelajari usaha dari bidang keahliannya. Inti pokok materi belajarnya yaitu mulai dari menganalisis peluang usaha bidang keahliannya, merencanakan produk kreatifnya, memproduksinya, menghitung kelayakannya, memasarkan, serta menyusun keuangan usaha tersebut. Mapel ini mengembangkan sikap, pengetahuan, keterampilan, dan pengalaman praktis kewirausahaan.

Disamping melalui mata pelajaran, pendidikan kewirausahaan di SMK/MAK juga dilaksanakan melalui praktik yang berbasis produksi dan bisnis pendukung mata pelajaran. Praktik tersebut diantaranya: Teaching Factory, Techno Park, Business Center dan Koperasi Siswa. Teaching factory adalah pembelajaran berbasis produksi/jasa yang mengacu kepada standar dan prosedur yang berlaku di industri, dan dilaksanakan dalam suasana seperti yang terjadi di industri (Manalu et al., 2017). Menurut Hadlock et al., (2008), dalam learning factory peserta belajar cara mendefinisikan masalah, membangun prototipe, menulis proposal bisnis, dan membuat presentasi tentang solusi mereka, bagaimana memenuhi tenggat waktu dan harapan, membangun dan bekerja di tim multidisiplin, dan menggunakan beragam bakat orang. Direktorat Pembinaan SMK mengungkapkan bahwa pengembangan nilai-nilai kewirausahaan dalam teaching factory yaitu: Karakter wirausaha: kemampuan/spirit mengatasi hambatan/halangan; Kemampuan berkompetisi: inovasi, efisiensi, kreatif; Kemampuan problem solving, decision making; Kemampuan dasar wirausaha: rencana bisnis, rencana keuangan, pemasaran, hubungan pelanggan, pembiayaan produk; Kemampuan berkomunikasi; Kemampuan produksi yang berorientasi ke customer; dan Interaksi dengan industri secara alami berdasarkan manfaat (Khurniawan et al., 2016). Berbagai teaching factory dari berbagai SMK dihimpun kedalam satu wadah yang disebut Technopark yang merupakan salah satu bentuk wadah (integrator) untuk menghubungkan antara SMK-SMK teaching factory dengan dunia industri. Technopark SMK menggabungkan ide, inovasi, dan knowhow dari berbagai SMK pelaksana teaching factory dan kemampuan finansial (dan marketing) dari dunia bisnis (Khurniawan et al., 2016). Secara konseptual teoretik, pendidikan kewirausahaan yang dilaksanakan melalui praktik teaching factory dan technopark memberikan bekal bagi siswa dan lulusan SMK untuk dapat memasuki era industri 4.0 secara kompetitif. Menurut (Hidayat, 2011), model teaching factory efektif meningkatkan kompetensi produktif siswa. Kompetensi tergambarkan pada nilai kognitif dan kompetensi vokasional (soft skill dan hard skill).

Business center atau Pusat Bisnis SMK merupakan kegiatan ekonomi yang diselenggarakan oleh sekolah dan ditujukan untuk masyarakat umum. Pada pusat bisnis dilakukan bisnis berbasis bidang keahlian siswa yang disebut bisnis center tehnopreneurship, seperti Bidang Otomotif membuka Bengkel Motor, Bidang Multi Media \& Broadcasting membuka Studio Foto dan Shooting, Bidang Audio Video dengan Bengkel Audio Video, bidang pemesinan dengan bengkel las dan bubut, dan bidang lain untuk bisnis lainnya seperti Bank mini, Apotik, Klinik kesehatan, dll (Hadam, Rahayu, \& Ariyadi, 2017). Pusat bisnis SMK dimulai tahun 2011 dan merupakan pengembangan dari program Unit Produksi. Unit Produksi merupakan bentuk pengembangan SMK berbasis industri yang paling sederhana (dimulai tahun 2000); kemudian dikembangkan lagi menjadi Unit Bisnis atau Bisnis Center sebagai pengembangan SMK berbasis industri yang berkembang; dan mulai tahun 2011 dikembangkan menjadi teaching factory sebagai pengembangan SMK berbasis industri yang berkembang dalam bentuk factory sebagai tempat belajar (Manalu et al., 2017). Praktik teaching factory, techno park, dan business center bagi Indonesia dapat diimplementasikan melalui wadah Koperasi Siswa. Pengaruh pusat bisnis terhadap kewirausahaan siswa SMK dibuktikan oleh penelitian (Rimadani \& Murniawaty, 2018) dan (Kuat, 2015) yang menyimpulkan bahwa kegiatan bisnis center berpengaruh terhadap jiwa kewirausahaan siswa. Koperasi siswa juga dapat meningkatkan skill berwirausaha (Arnila, 2017).

Pada jenjang pendidikan tinggi, pendidikan kewirausahaan dilaksanakan secara terpisah dan juga terintegrasi. Pendidikan kewirausahaan yang dilaksanakan secara terpisah diselenggarakan melalui mata kuliah kewirausahaan dan atau kegiatan ekstra kurikuler kewirausahaan, sedangkan yang terintegrasi diselenggarakan melalui mata kuliah non kewirausahaan ataupun kegiatan intra 
kurikuler. Tingkatan kompetensi kewirausahaan pada pendidikan tinggi dapat dibagi menjadi kompetensi kewirausahaan dasar, menengah, dan lanjut, yang ranahnya mencakup ranah afektif, kognitif, dan psikomotor (Sumarno et al., 2018). Tiga tingkatan kompetensi kewirausahaan tersebut untuk menyesuaikan kemampuan awal kewirausahaan mahasiswa. Mahasiswa yang berasal dari SMA/MA memerlukan kompetensi kewirausahaan dasar hingga lanjut, sedangkan mahasiswa yang berasal dari SMK/MAK cenderung cukup dengan kompetensi kewirausahaan lanjut atau menengah. Hasil penelitian Kurjono, Mulyani, \& Murtadlo (2018) menunjukkan bahwa minat kewirausahaan mahasiswa jurusan ilmu sosial lebih tinggi dibanding mahasiswa jurusan sains. Hal itu dapat dimaklumi karena mahasiswa jurusan ilmu sosial pada umumnya berasal dari SMA/MA jurusan Ilmu Sosial yang telah mendapat pelajaran terkait kewirausahaan atau ekonomi. Di samping itu juga dapat berasal dari SMK/MAK yang sudah banyak mendapatkan kewirausahaan baik dari pelajaran maupun praktik.

Secara umum pendidikan kewirausahaan di pendidikan tinggi dapat diselenggarakan melalui perkuliahan kewirausahaan, pelatihan kewirausahaan, Program Kreativitas Mahasiswa bidang Kewirausahaan (PKM-K), Magang atau Coop Usaha, Program Mahasiswa Wirausaha (PMW) atau Kompetisi Bisnis Mahasiswa (KBMI), Inkubator Bisnis, Kuliah Kerja Usaha (KKU), maupun Koperasi Mahasiswa (Sumarno et al., 2018); (Siswoyo, 2009). Pengembangan kewirausahaan di pendidikan tinggi sebaiknya berbasis technopreneurship agar kewirausahaan yang dijalankan mahasiswa atau lulusannya berbasis ilmu pengetahuan yang memadai sehingga tidak menjadi pesaing usaha-usaha kecil. Untuk dapat mengembangkan technopreneur di pendidikan tinggi perlu adanya integrasi kewirausahaan kedalam perkuliahan bidang ilmu jurusan sehingga mahasiswa mampu memanfaatkan ilmu bidang jurusannya untuk menjadi basis usahanya. Di samping pengitegrasian kewirausahaan dalam kuliah bidang ilmu jurusan/program studi (prodi), diperlukan juga adanya unit khusus yang menangani/mengelola kegiatan kewirausahaan mahasiswa dari tingkat prodi/jurusan hingga tingkat universitas/lembaga pendidikan tingginya.

\section{PENUTUP}

Melalui pendidikan kewirausahaan, tuntutan sumber daya manusia era industri 4.0 yang berupa kemampuan berpikir kritis, kreatif dan inovatif, komunikatif, kolaboratif, percaya diri, koordinatif, tanggung jawab, mengambil keputusan, memecahkan masalah, beradaptasi, dan kepemimpinan) dapat dipenuhi oleh nilai-nilai pokok atau jiwa dan sikap kewirausahaan yang dihasilkan dari pendidikan kewirausahaan. Terpenuhinya tuntutan kemampuan sumber daya manusia pada era industri 4.0, dampak positif yang ditimbulkannnya dapat diraih. Bila peluang usaha yang ada dapat diraih, maka tercipta peluang kerja yang baru karena kemampuan sumber daya manusia yang ada sudah sesuai tuntutannya. Diraihnya peluang kerja dan peluang usaha era industri 4.0, akan mengatasi dampak negatifnya yang berupa pengangguran akibat pergeseran pekerjaan. Hal yang demikian menunjukkan bahwa pendidikan kewirausahaan dapat menjadi solusi atas dampak dan tuntutan era industri 4.0 Indonesia.

Pendidikan kewirausahaan seharusnya diselenggarakan mulai dari pendidikan pra sekolah hingga pendidikan tinggi. Pada jenjang pendidikan pra sekolah, pendidikan kewirausahaan dilaksanakan secara terintegrasi dalam kegiatan bermain anak. Tujuannya utamanya untuk menanamkan/menumbuhkan nilai-nilai atau sikap dan karakter kewirausahaan. Pada jenjang pendidikan dasar (SD dan SMP), pendidikan kewirausahaan diselenggarakan secara terintegrasi dalam Mata Pelajaran (Mapel) non kewirausahaan. Tujuannya untuk membentuk dan mengembangkan sikap dan karakter kewirausahaan serta pengenalan pengetahuan kewirausahaan.

Pada jenjang pendidikan mengah SMA/MA, pendidikan kewirausahaan untuk memberikan pengetahuan serta mengembangkan sikap dan keterampilan kewirausahaan terkait bidang ilmu pengetahuannya. Pada SMK/MAK pendidikan kewirausahaan untuk mengembangkan sikap, pengetahuan, keterampilan, dan penglaman kewirausahaan. Selain melalui Mapel, keterampilan 
kewirausahaan harus dipraktikkan melalui kegiatan usaha nyata dalam bentuk pendirian dan penyelenggaraan unit-unit bisnis secara komprehensif sebagai implementasi kompetensi bidang keahlian dan kewirausahaannya seperti Teaching factory, Techno park, Business center ataupun Koperasi Siswa.

Pada jenjang pendidikan tinggi, pendidikan kewirausahaan sebaiknya diselenggarakan secara terpisah/khusus melalui Mata Kuliah (Makul) Kewirausahaan dan juga terintegrasi melalui Makul lainnya. Makul Kewirausahaan untuk memberikan pengetahuan serta mengembangkan sikap dan keterampilan kewirausahaan. Makul lainnya untuk mengembangkan sikap dan keterampilan kewirausahaan terkait bidang ilmu pengetahuannya. Implementasi keterampilan kewirausahaan berbasis bidang ilmu dapat dilaksanakan melalui program-program kreativitas mahasiswa, kewirausahaan mahasiswa, bisnis mahasiswa, coop mahasiswa, Koperasi Mahasiswa, dan unit-unit bisnis lainnya yang sebaiknya dikoordinasikan oleh lembaga/unit khusus pengelola kewirausahaan perguruan tinggi atau terintegrasi pada unit-unit kegiatan mahasiswa mulai dari level program studi hingga level perguruan tinggi.

Penyelenggaraan pendidikan kewirausahaan secara sinergis, integratif, dan berkelanjutan dari jenjang pendidikan usia dini hingga pendidikan tinggi akan memberikan kompetensi kewirausahaan yang komprehensif untuk meraih peluang era industri 4.0 melalui penciptaan pekerjaan bagi dirinya dan masyarakatnya.

Untuk terselenggaranya dan tercapainya tujuan pendidikan kewirausahaan secara lebih efeektif, disarankan:

1. Perlu koordinasi dan sinkronisasi antar jenjang pendidikan untuk pembentukan dan pengembangan sikap, pengetahuan, keterampilan, dan pengalaman kewirausahaan yang aplikatif dan berkesinambungan/berkelanjutan.

2. Perlu koordinasi dan integrasi antar guru atau dosen, mata pelajaran atau mata kuliah, unit dalam internal satuan pendidikan untuk efektifitas pendidikan kewirausahaan.

3. Perlu dibangun dan dikembangkan sinergitas antar/antara sekolah, perguruan tinggi, pemerintah, DUDI, dan masyarakat untuk mengembangkan kewiraushaan siswa, mahasiswa, dan masyarakat.

\section{DAFTAR PUSTAKA}

Alma, B. (2010). Kewirausahaan (Revisi). Bandung: Alfabeta.

Angriani, D. (2018). Revolusi Industri 4.0 dan Kesiapan Tenaga Kerja Indonesia. https://doi.org/http://news.metrotvnews.com/read/2018/02/05/827025/revolusi-industri-4-0dan-kesiapan-tenaga-kerja-indonesia

Arasti, Z., Mansoreh, K. F., \& Imanipour, N. (2012). A Study of Teaching Methods in Entrepreneurship Education for Graduate Students. Higher Education Studies, 2(1), 2-10. https://doi.org/10.5539/hes.v2n1p2

Ariyanti, H. (2018). Hadapi Revolusi Industri 4.0, Mendikbud akan rancang ulang kurikulum. https://doi.org/https://www.merdeka.com/peristiwa/hadapi-revolusi-industri-40-mendikbudakan-rancang-ulang-kurikulum.html

Arnila, R. A. (2017). Penerapan Model Experiential Learning berbasis Kreativitas melalui Media Koperasi Sekolah pada Pembelajaran Prakarya dan Kewirausahaan untuk Meningkatkan Skills Berwirausaha Siswa. Universitas Sebelas Maret.

https://doi.org/https://eprints.uns.ac.id/id/eprint/33369 
Bourgeois, A. (2012). Entrepreneurship Education at School in Europe: National Strategies, Curricula and Learning Outcomes. Brussels. https://doi.org/10.2797/80384

Brodjonegoro, S. S. (2018). Kecakapan Era 4.0. Kompas, 14 Februari 2018, 0, 1-2. https://doi.org/https://kompas.id/baca/opini/2018/02/14/kecakapan-era-4-0/

Čapienè, A., \& Ragauskaite, A. (2017). Entrepreneurship education at university: innovative models and current trends, 2, 284-291. https://doi.org/10.22616/rrd.23.2017.080

Carcamo-Solís, M. de L., Arroyo-Lopez, M. del P., Alvarez-Castanon, L. del C., \& García-Lopez, E. (2017). Developing entrepreneurship in primary schools . The Mexican experience of "My fi rst enterprise : Entrepreneurship by playing ." Teaching and Teacher Education, 64, 291304. https://doi.org/10.1016/j.tate.2017.02.013

Diwan, P. (2017). Is Education 4.0 an imperative for success of 4th Industrial Revolution? https://doi.org/https://medium.com/@pdiwan/is-education-4-0-an-imperative-for-success-of4th-industrial-revolution-50c31451e8a4

Faidah, N., Harti, \& Subroto, W. T. (2018). Pengaruh Pengalaman Ekonomi, Kontrol Diri Serta Pendapatan Siswa Terhadap Perilaku Ekonomi Siswa SMA di Kecamatan Pasir Belengkong Kabupaten Paser. Jurnal Ekonomi Pendidikan Dan Kewirausahaan, 6(1), 59-82. https://doi.org/DOI: 10.26740/jepk.v6n1.p59-82

Fitroni, Z. (2017). Peningkatan Minat Kewirausahaan Siswa SMP dengan Pendekatan Scientific Sell. JINoP (Jurnal Inovasi Pembelajaran), 3(November), 659-670.

https://doi.org/https://doi.org/10.22219/jinop.v3i2.4556

Hadam, S., Rahayu, N., \& Ariyadi, A. N. (2017). STRATEGI IMPLEMENTASI REVITALISASI SMK. Jakarta: Direktorat Pembinaan Sekolah Menengah Kejuruan Direktorat Jenderal Pendidikan Dasar dan Menengah Kementerian Pendidikan dan Kebudayaan RI.

Hadlock, H., Wells, S., Hall, J., Clifford, J., Winowich, N., \& Burns, J. (2008). From Practice to Entrepreneurship: Rethinking the Learning Factory Approach. In The 2008 IAJC-IJME International Conference. IAJC-IJME.

https://doi.org/http://ijme.us/cd_08/PDF/81\%20ENT\%20P\%20401.pdf

Haeffner, M., \& Panuwatwanich, K. (2018). Perceived Impacts of Industry 4.0 on Manufacturing Industry and its Workforce: Case of Germany. In 8th International Conference on Engineering, Project, and Product Management (EPPM 2017) (pp. 0-10). https://doi.org/10.1007/978-3-319-74123-9

Handrimurtjahjo, A. D. (2013). Model Pembelajaran Kewirausahaan Di Perguruan Tinggi. Jurnal Universitas Paramadina, 10(2), 729-755.

Harkins, A. M. (2008). Leapfrog Principles and Practices: Core Components of Education 3.0 and 


\subsection{Futures Research Quarterly, 24 No. 1, 1-15.}

https://doi.org/http://leapfrog.umn.edu/Documents/HarkinsCoreComponents.pdf

Harususilo, Y. E. (2018). Ki Hadjar Dewantara dan "Guncangan" Pendidikan Era Industri 4.0. https://doi.org/https://edukasi.kompas.com/read/2018/05/02/15561621/ki-hadjar-dewantaradan-guncangan-pendidikan-era-industri-40.

Hassi, A. (2016). Effectiveness of Early Entrepreneurship Education at The Primary School Level: Evidence from a field research in Morocco. Sage Journals, Volume: 15(2), 83-103. https://doi.org/10.1177/2047173416650448

Herlambang, Y. T. (2018). PEDAGOGIK: Telaah Kritis Ilmu Pendidikan dalam Multiperspektif. (Y. Abidin, Ed.) (Pertama). Jakarta: Bumi Aksara.

Hermansyah, A., Natuna, D. A., \& Sumarno. (2017). Kontribusi Pelaksanaan Pembelajaran Kewirausahaan dan Interaksi Sosial terhadap Karakter Kewirausahaan Peserta Didik MAN 1 Pekanbaru. Jurnal Pekbis, Vol.9, No., 104-113.

Hidayat, M. D. (2011). MODEL PEMBELAJARAN TEACHING FACTORY UNTUK MENINGKATKAN KOMPETENSI SISWA DALAM MATA PELAJARAN PRODUKTIF. Jurnal Ilmu Pendidikan, Vol. 17, N, 270-278.

https://doi.org/http://dx.doi.org/10.17977/jip.v17i4.2729

Irianto, D. (2017). Industry 4.0: The Challenges of Tomorrow. https://doi.org/k8bksti.ub.ac.id/wpcontent/uploads/2017/10/Keynote-Speaker-Dradjad-Irianto.pdf

Jati, B. M. E., \& Priyambodo, T. K. (2015). KEWIRAUSAHAAN-Technopreneurship untuk Mahasiswa Ilmu-ilmu eksakta. Yogyakarta: ANDI Yogyakarta.

Kagermann, H., Wahlster, W., \& Helbig, J. (2013). Securing the future of German manufacturing industry: Recommendations for implementing the strategic initiative INDUSTRIE 4.0. Final Report of the Industrie 4.0 Working Group, (April), 1-84.

https://doi.org/10.13140/RG.2.2.14480.20485

Kautsar, S., \& Ibrahim, S. M. (2018). Tantangan Pendidikan Era Revolusi Industri 4.0. https://doi.org/https://um.ac.id/content/page/2/2018/11/tantangan-pendidikan-era-revolusiindustri-4-0

Kemdikbud RI. (2016). Silabus Mata Pelajaran Prakarya dan Kewirausahaan SMA/MA/SMK/MAK. Kementerian Pendidikan dan Kebudayaan Republik Indonesia.

Khurniawan, A. W., Akbar, W. J., Widjajanti, C., Razik, rfah L., Suliswanto, H., \& Rifan, M. (2016). GRAND DESIGN PENGEMBANGAN TEACHING FACTORY DAN TECHNOPARK DI SMK. (A. W. Khurniawan \& T. Haryani, Eds.). Jakarta: Direktorat Jenderal Pendidikan Dasar dan Menengah Kementerian Pendidikan dan Kebudayaan Republik Indonesia. 
Klingenberg, C. O. (2017). Industry 4 . 0: what makes it a revolution?, (July), 1-10. https://doi.org/https://www.researchgate.net/publication/319127784_Industry_40_what_make s_it_a_revolution

Kodrat, D. S., \& Christina, W. (2015). Entrepreneurship sebuah ilmu. (O. M. Dwiasri \& N. I. Sallama, Eds.). Jakarta: Erlangga.

Kuat, T. (2015). Penumbuhan Jiwa Kewirausahaan Melalui Praktik Bisnis di Business Center ( Studi kasus: SMK Muhammadiyah 2 Surakarta). Jurnal Pendidikan Ilmu Sosial, Vol 25, No(1), 155-168. https://doi.org/10.2317/jpis.v25i1.827

Kurjono, Mulyani, H., \& Murtadlo, Y. (2018). A Model of Entrepreneurial Intention Through Behavioral Approaches. Dinamika Pendidikan, 13(2), 185-197.

https://doi.org/10.15294/dp.v13i2.17051

Lee, J., Lapira, E., Bagheri, B., \& Kao, H. (2013). Recent Advances and Trends in Predictive Manufacturing Systems in Big Data Environment. Manufacturing Letters, 1, 2013(October), 38-41. https://doi.org/10.1016/j.mfglet.2013.09.005

Linangkung, E. (2017). Revolusi Industri, 75\% Jenis Pekerjaan Akan Hilang. https://doi.org/https://ekbis.sindonews.com/read/1183599/34/revolusi-industri-75-jenispekerjaan-akan-hilang-1488169341

Manalu, S. R. I., Hermanto, S., Duling, J. R., Siswandi, G., Supriyadi, \& Siahaan, A. P. (2017). Tata Kelola Pelaksanaan Teaching Factory. Jakarta: Direktorat Pembinaan Sekolah Menengah Kejuruan Direktorat Jenderal Pendidikan Dasar dan Menengah Kementerian Pendidikan dan Kebudayaan RI.

Mulyani, E., Suharyadi, Sejati, V. S., Sistaningrum, W., Winarno, G., Gunawan, A. S., ... Usman, H. (2010). PENGEMBANGAN PENDIDIKAN KEWIRAUSAHAAN. Jakarta: Pusat Kurikulum Badan Penelitian dan Pengembangan Kementerian Pendidikan Nasional RI. https://doi.org/http://blog.undana.ac.id/jsmallfib_top/LPMPTBUKUDIKTI/3__Kewirausahaa n.pdf

Raposo, M., \& Paço, A. (2011). Entrepreneurship education: Relationship between education and entrepreneurial activity, 23(2011), 453-457.

Rasmussen, A., Moberg, K., \& Revsbech, C. (2015). A Taxonomy of Entrepreneurship Education Pepspectives on Goals, Teaching and Evaluation. Odense C, Denmark: The Danish Foundation for Entrepreneurship.

Rimadani, F., \& Murniawaty, I. (2018). Pengaruh Pendidikan Kewirausahaan, Business Center, dan Kreativitas Siswa Terhadap Jiwa Berwirausaha Siswa. Economic Education Analysis Journal, 7(3), 976-991. https://doi.org/https://doi.org/10.15294/eeaj.v7i3.28333 
Safitri, N. M. (2015). IMPLEMENTASI PENDIDIKAN KARAKTER MELALUI KULTUR SEKOLAH DI SMP N 14 YOGYAKARTA. Jurnal Pendidikan Karakter, Tahun V, N, 173183. https://doi.org/https://journal.uny.ac.id/index.php/jpka/article/view/8621/7114

Safuan, S. (2018). Perencanaan Tenaga Kerja \& Pengembangan SDM Menghadapi Revolusi Industri 4.0.

https://doi.org/http://disnakertrans.jatengprov.go.id/assets/pengunjung/upload/publikasi/PTK_Jaten g_MEI_2018.pdf

Santika, T. (2017). PENDIDIKAN KARAKTER KEWIRAUSAHAN PADAPROGRAM PENDIDIKAN ANAK USIA DINI ( PAUD ) EDUCATION OF ENTREPRENEURIAL CHARACTER IN EARLY CHILDHOOD EDUCATION PROGRAMS. In Seminar Nasional Pendidikan Nonformal FKIP Universitas Bengkulu (Vol. 1, pp. 33-46).

https://doi.org/http://repository.unib.ac.id/11760/1/4.\%20Tika\%20Santika\%20PENDIDIKAN\%20 KARAKTER\%20KEWIRAUSAHAN\%20PADA\%20\%20PROGRAM\%20PENDIDIKAN\% 20ANAK\%20USIA\%20DINI\%20\%28PAUD\%29.pdf

Saputra, Y. N. (2011). Pengembangan Kurikulum Kewirausahaan di Sekolah Menengah Pertama. Jurnal Pendidikan Dan Kebudayaan, Vol. 17, N, 599-607.

https://doi.org/http://jurnaldikbud.kemdikbud.go.id/index.php/jpnk/article/view/52 10.24832/jpnk.v17i5.52

Siswoyo, H. B. B. (2009). Pengembangan Jiwa Kewirausahaan di Kalangan Dosen dan Mahasiswa. JURNAL EKONOMI BISNIS, Vol. 14, N, 114-123.

Sulistyowati, P., \& Salwa. (2016). UPAYA MENGEMBANGKAN KARAKTER JIWA KEWIRAUSAHAAN PADA SISWA SEJAK DINI MELALUI PROGRAM MARKET DAY (KAJIAN PADA SDIT MUTIARA HATI MALANG) Prihatin Sulistyowati 14, Salwa 15. Pancaran, Vol. 5, No(20), 111-120.

https://doi.org/https://jurnal.unej.ac.id/index.php/pancaran/article/view/4056/3169

Sumarno, Gimin, Haryana, G., \& Saryono. (2018). Desain Pendidikan Kewirausahaan Mahasiswa Berbasis Technopreneurship. Jurnal Ekonomi Pendidikan Dan Kewirausahaan, 6(2), 171186. https://doi.org/10.26740/jepk.v6n1.p171-186

Sumarno, \& Suarman. (2017). Development of technopreneurship-based entrepreneurship education for students at Universitas Riau, Indonesia. International Journal of Economic Research, 14(12), 65-74.

https://doi.org/http://serialsjournals.com/articles.php?volumesno_id=1332\&journals_id=41\&volum es_id $=1068$

Sung, T. K. (2018). Industry 4.0: Korea Perspective. Technological Forecasting and Social Change 
Journal, 132 (2018), 40-45. https://doi.org/https://doi.orgllO,1016/j.techfore.2017.11.005

Suryaman, \& Karyono, H. (2017). Developing entrepreneurship in primary schools. The Mexican experience of "My first enterprise: Entrepreneurship by playing." 3rd International Conference on Education and Training (ICET 2017); Advances in Social Science, Education and Humanities Research, 128(Icet), 135-139. https://doi.org/https://www.atlantispress.com/search?q=Leading+Entrepreneurship+Education-

Based+Primary+Schools\&author=Suryaman\&title=Leading+Entrepreneurship+Education-

Based+Primary + Schools\&keyword $=$ design $\% 2 \mathrm{C}+$ leading + school $\% 2 \mathrm{C}+$ enterpreneur\&type $=$ pr oceedings

Suryana. (2013). Kewirausahaan: Kiat dan proses Menuju Sukses (4th ed.). Jakarta: Salemba Empat.

Suwardana, H. (2017). Revolusi Industri 4 . 0 Berbasis Revolusi Mental. Jati Unik, 1(2), 102-110. https://doi.org/http://ojs.unik-kediri.ac.id/index.php/jatiunik/article/view/117/0

Syaifuddin, I., \& Kalim, A. (2016). MODEL PENDIDIKAN KEWIRAUSAHAAN DI SMP ALAM AR RIDHO KOTA SEMARANG TAHUN 2016. Quality, Vol. 4, No(2), 331-350. https://doi.org/http://journal.stainkudus.ac.id/index.php/Quality/article/view/2175/1815

Tanaya, I. (2018). Revolusi Industri 4.0, Ancaman atau Berkah?

https://doi.org/https://www.kompasiana.com/www.inatanaya.com/5ad6f349ab12ae1f2d68f1b2/rev olusi-industri-4-0-ancaman-atau-berkah?page=all

Tilaar, H. A. R. (2012). Pengembangan Kreativitas dan Entrepreneurship dalam Pendidikan Nasional (Pertama). Jakarta: Kompas.

Weber, S., \& Funke, S. (2012). An «instructional» perspective on entrepreneurship education focusing on the development of team competencies. Empirical Research in Vocational Education and Training, 4(1), 49-72.

Werdhaningsih, H., Haryudanti, A., Jamrianti, R., \& Wirmas, D. (2017). Prakarya dan Kewirausahaan: Buku Guru (3, Revisi ed.). Jakarta: Pusat Kurikulum dan Perbukuan, Balitbang, Kemendikbud.

Williamson, N., Beadle, S., \& Charalambous, S. (2013). Enterprise Education Impact in Higher Education and Further Education. London.

https://doi.org/https://www.aoc.co.uk/sites/default/files/ENTERPRISE EDUCATION IMPACT IN HIGHER EDUCATION AND FURTHER EDUCATIONFull_Report.pdf Zuchdi, D., Prasetya, Z. K., \& Masruri, M. S. (2013). MODEL PENDIDIKIIN KARAKTER Terintegrasi Dalam Pembelajaran dan Pengembangan Kultur sekolah. Yogyakarta: Multi Pressindo. 